\title{
戦前地方都市における都市計画の策定経緯と事業化

\author{
〜松江市を事例に〜
}

\section{HISTORY OF THE DEVISING OF A CITY PLAN AND THE IMPLEMENTATION OF THE PLAN IN A LOCAL CITY IN THE PREWAR PERIOD}

- With reference to the case of Matsue city -

\author{
中野茂夫*1
}

\section{Shigeo NAKANO}

\begin{abstract}
This study aims to clarify the realities of city improvement in the prewar period with reference to the case of Matsue City. The city-planning project of Matsue City ended up with only one city-planned street being developed as a state-aided unemployment relief project. However, it is clear that the civil development plans achieved a certain degree of success as evidenced by the landfill project implemented as part of the partial rerouting of the Hii River, road improvement by central and prefectural authorities, an unemployment relief project, land readjustment of fire-damaged areas, and the forced relocation of buildings.
\end{abstract}

Keywords : Legal city planning, Local city, Matsue, City planning street, Land readjustment 法定都市計画，地方都市，松江，都市計画街路，土地区画整理

\section{はじめに}

地方都市を題材とした都市計画史研究に関しては、国立公文書館 所蔵「公文雑纂」をはじめとする公文書を主史料とすることで、法 定都市計画の計画や事業の具体的な内容や空間的な特徵、都市計画 地方委員会の計画意図等について明らかにされつつある注1)。しかし 通常、計画決定に関する公文書に揭載されている情報は限られてい るため、計画段階における調査や計画策定における議論の様子、地 元の動向等も含めた総体的な策定プロセスを明らかにした研究は少 ない。とくに第二次世界大戦前（以下「戦前」）の都市計画事業は すでに指摘されるように財源の関係から限定的であり注2)、都市計画 の決定事項にそくして別途行われた各種事業によって都市整備が進 められていたことが指摘されているが、その具体的な内容にまで踏 み込んだ地方の都市計画史研究はあまりない注3)。

そこで、本研究では戦前の松江における都市計画の実相につい て、計画策定の経緯と事業化の観点から総体的に明らかにすること を目的とする。ここで报う「都市計画」は、法定都市計画として計 画決定には至らなかったものの実際に策定が検討されていたもの や、都市計画事業によらない各種事業も含めて広い範囲で捉えてい る。そうすることによって法定都市計画の軌跡を追いかけるだけで は見えてこない地方都市の市街地整備について再評価することがで きるのではないかと考えている。本稿はあくまで松江を対象とした 個別事例の検討にすぎないが、こうした事例を積み重ねることによ って財政の逼迫から否定的な見方がされている戦前の地方都市にお ける都市計画のあり様やその特質を浮き彫りにすることにつながる という見通しに立っている。
計画策定の経緯については、松江市では都市計画区域と都市計画 街路の決定が重要な審議事項だったが（Tablel）、まず都市計画法 の適用に向けて実際に行われた「都市計画準備調査」の調査内容と 計画の素案を明らかにする。その上で「都市計画準備調査」の成果 や都市計画島根地方委員会における審議、市行政の意向等と照らし 合わせながら、松江における都市計画の策定経緯について明らかに する。その際、松江の都市計画導入期に長らく市長を務めた石倉俊 寛の言説にも注目する必要がある。本研究では計画策定の経緯も分 析対象に含めているため、法定都市計画としては計画決定には至ら なかったものの、実際に計画が検討されていた湖岸道路や用途地域 も取り上げる。一方、事業化に関しては、Tablelに示すように都市 計画事業は一等大路三類一号線と二等大路三類六号線が事業決定し ただけであったが、都市計画街路にそくして各種事業が施工されて いたため、それらも含めて分析を行う。とりわけ火災からの復興は 他の例にもれず、地方において都市計画街路が整備される重要な契 機だったため、それに関連する公共団体施行以外の土地区画整理事 業についても詳述する。また本研究は社会システムの断絶もふまえ て戦前までを対象としているが、戦時中の建物疎開については、史 料の制約から戦後直後の後処理でしか実態を把握できないため、対 象に含めている。

なお、戦前松江市の都市計画については『松江市誌』注4)に事実内 容が紹介されているが、計画策定の過程やそれに関連する議論等に ついては十分述べられていない。また先行研究の脇田（1999）注5） は都市施設の分布状況に重点を置いており、法定都市計画の具体的 な内容については『松江市誌』以上の情報を提示していない。

*1 大阪市立大学大学院生活科学研究科 教授 - 博士 (都市 $\cdot$ 地域計画)

Prof., Graduate School of Human life Science, Osaka City University, Ph.D 
Table1 Matsue city planning chronology

\begin{tabular}{|c|c|c|c|}
\hline \multirow[t]{2}{*}{ date } & \multirow[t]{2}{*}{ city planning decision } & \multicolumn{2}{|c|}{$\begin{array}{c}\text { City Planning } \\
\text { Shimane Regional } \\
\text { Council }\end{array}$} \\
\hline & & No. & date \\
\hline 1928-10-01 & city planning area & 1 & 1928.9.4 \\
\hline 1930-01-21 & change of city planning area & 2 & 1929.12.24 \\
\hline 1931-01-01 & application of Urban Building Law & - & \\
\hline 1932-12-09 & city planning street & 3 & 1932.7.11 \\
\hline 1933-10-02 & city planning street project and schedule [Fig.1-I.3.1] & 4 & 1933.9.18 \\
\hline 1934-01-24 & land expropriation of city planning street & - & \\
\hline $1937-08-07$ & city planning street project and schedule [Fig.1-II.3.6] & \multirow{2}{*}{6} & \multirow{2}{*}{ 1937.7.26 } \\
\hline $1937-08-25$ & tax on beneficiaries for city planning street & & \\
\hline \multirow{2}{*}{ 1938-04-05 } & change of city planning street project and schedule [Fig.1-II.3.6] & \multirow{2}{*}{7} & \multirow{2}{*}{ 1938.3.22 } \\
\hline & partial change of city planning street [Fig.1-II.2.4] & & \\
\hline 1939-03-31 & change of city planning street project and schedule [Fig.1-II.3.6] & 8 & 1939.3.22 \\
\hline 1941-03-31 & change of city planning street project and schedule [Fig.1-II.3.6] & 10 & 1941.3 .31 \\
\hline 1944-07-07 & $\begin{array}{l}\text { partial change and discontinuance of city planning street project } \\
\text { partial change[Fig.1-II.3.1, II.3.2], discontinuance [Fig.1-II.3.6] }\end{array}$ & 12 & 1944.6.10 \\
\hline 1946-11-09 & reconstruction city plan of production city and shedule & 13 & 1946.9.17 \\
\hline
\end{tabular}

"Koubun Zassan", National Archives of Japan and "Document of shimane urban planning council", in the possession of Shimane prefectural official archive center.

\section{1. 都市計画準備調査}

松江市では大正10年度から都市計画準備調査に着手しており、大 正11年7月4日の市会の議決にもとづいて都市計画準備調査委員が設 置された。調査委員は市会議員と選挙で選ばれた公民、学識経験者 で構成されており、第一部「交通地域の指定に関する件」、第二部 「下水道其の他衛生上設備に関する件」、第三部「築港及埋立に関 する件」、第四部「市区拡張に関する件」の4部会に分かれて調査が 進められることになった。そして大正11年11月22日に開催された第 一回調査委員会で定めた調査方針にもとづいて都市計画の基礎調査 が開始された。

一方、大正13年10月15日には内務省都市計画局長から「都市計画 法第二条ノ規定二依ル市指定二関スル件」（内務省発第五四号）が 各道府県に通牒され、「都市計画ノ施設ノ必要」を客観的に示す上 でも詳細な調査が求められており、その趣旨にそって都市計画準備 調査が実施されることになった。大正14-15年度に臨時都市計画準備 調査委員規定が定められ、35名の委員（市会議員 30 名・その他5名） によって各項目の調査に対する意見がまとめられ、市長に報告され ることになった。また調査に応じて学識経験者を顧問を嘱託し、委 員会の参与とすることとされた。「都市計画準備調査一途」注6)には 調査の方針についてつぎのように記されている。

…本市八先ツ以テ人口十万ヨ包容スーキ都市ノ建設ヨ企図シ、松江大橋 7 原 点トセル半径一哩半/圈内二於テ別表/如ク本計画上必要ナル各種/準備的調 査ヨ為セリ、而シテ此調査ノ区域八本市ノ外二郊外地夕ル津田、乃木、法吉、 川津ノ四村二跨リ面積約五百四十七万坪ニシテ本市現在面積ノ約三倍八分二当 レリ。

このことから、松江市では人口10万人以上の都市を目指してお り、松江大橋を原点として半径1.5マイル圏内を調查対象地に設定し ていたことがわかる。その範囲は、松江市だけでなく、隣接する旧 津田、乃木、法吉、川津の4ヶ村に及んでおり、郊外も含めた都市計 画区域を想定していた。松江市の都市計画準備調査は大正15年6月に 完了し、都市計画法適用に向けた禀請書が提出されることになっ た。一連の調査の結果、「準備調査街路一覧表」「市内堀川整理計 画」「突道湖面埋立計画一覧表」「都市計画地域地区一覧表」「死
亡率統計」に関する資料が作成された注7)。なお、下水改良調查は未 了だったという。

「準備調查街路一覧表」によれば、一等大路 22 路線・総延長 18,111 間、二等大路 19 路線・総延長 14,219 間、二等小路 11 路線・総 延長 5,800 間となっており、合計 51 路線、総延長 38,130 間（約 $68,634 \mathrm{~m})$ であったことがわかる。一等大路の幅員は大半が12間 (含一部6間) であった（18間、13.5間、13間が各1路線）。二等大 路と二等小路の幅員はすべて6間と3間であった。とりわけ広幅員の 一等大路の路線数が多いことが特徵として挙げられる。

「市内堀川整理計画」では、7つの堀川（四十間堀・北堀・京橋 川・米子川・瀬田橋川・中堀・小堀）の整理を計画しており、総延 長2,183.5間、面積15,910.7坪であった。この内、中心市街地を流れ る京橋川の埋め立てが、延長820.5間、面積5,746坪となっており、 最大規模になっていることがわかる。戦後、京橋川を埋め立てて都 市計画街路とする計画が策定されたが、ここにその端緒が確認され る。一方、「宍道湖面埋立計画」は、末次町で延長 268 間、面積 8676坪、横浜町・幸町で延長306間、面積 14,200 坪の合計 22,876 坪 を埋め立てるという計画になっていた。前者が湖岸道路湖北線、後 者が同湖南線に該当しており、後述する湖岸道路の整備とも関連し ていたと推定される。また「都市計画地域地区一覧表」によれば、 住居地域 $1,557,000$ 坪、商業地域442,000坪、工業地域245,000坪、 公園地区 318,000 坪、風致地区 100,000 坪、未指定地域449,000坪、 未指定地域以外の山地等が837,323坪と見積もられており、総計は $3,948,323$ 坪であった。当時の松江市の市域は、1,406,336坪であ り、周辺市町村も含めて都市計画区域を設定し、地域地区を定める 予定だったことが窥える。

\section{2. 都市計画区域の決定}

昭和3年9月4日に第一回都市計画島根地方委員会が開催され、松江 市の都市計画区域について審議が行われた。同委員会幹事の竹内常 八の説明から、都市計画区域は一人当たりの面積をもとに算出し、 範囲を決定していたことがわかる。当時、都市計画区域内における 標準は、市部で 1 人当たり 25 坪、郡部で1人当り 80 坪とされており、 旧松江市域ではすでに 1 人当り 29 坪4合に達していたため、やや過密 であることが指摘されている。先述のように、松江市の都市計画準 備調査は松江大橋を中心に隣接 4 个村も含めて行われており、本来な ら周辺の郡部も含めて議論する必要があるが、このときは松江市域 のみを都市計画区域に設定することが審議されている。というの も、昭和 2 年 12 月に灘町で大火が発生したため、急遽、復興に迫られ ることになり、そのための土地区画整理を施行するためには、速や かに都市計画法を適用し、都市計画区域を定める必要があったから である。このため第一回都市計画島根地方委員会の議論では、今回 の区域設定はあくまで火災復興という特殊な事情を考慮した暫定的 な措置であり注8)、周辺地域への都市計画区域の拡張は今後検討する ことになった。こうして松江市の都市計画区域は、昭和3年10月1日 に市域のみを範囲として計画決定されたが、本来、都市計画区域は 郊外の市街化を抑制するために周辺地域も含めて設定するものであ り、今回の決定はそれに該当しないはじめての例であったという。

もちろん、こうした経緯だったから、昭和4年12月3日に内務省か ら都市計画区域拡張の諮問があり、第二回都市計画島根地方委員会 
で審議されることになった。都市計画島根地方委員会では、榧木寛 之内務技師の内示にもとづき、都市計画区域の範囲を検討し、最終 的に導き出した原案は、松江市域に法吉村、津田村、乃木村、朝酶 村の一部、川津村の一部を加えた区域であり、拡張後の都市計画区 域の総面積は 1,065 万 8,636 坪、利用可能面積は 602 万 7,847 坪（市部 $1,220,447$ 坪、郡部4,807,400坪）と算出された。先述の市部および 郡部の 1 人当たりの標準面積から当該区域には人口 10 万 8,910 人を収 容できると見積もられている。これは都市計画準備調査で想定して いた計画人口とも対応していよう。ただし朝酌村の一部が追加され ている点、川津村が一部のみに変更されている点で、都市計画基礎 調查の対象範囲とは若干異なっている。昭和 2 年末の人口（松江市 43,613 人で郡部含めて 5 万人余) に年平均人口増加数 846 人（市部 774 人、郡部 72 人) を足し合わせた結果、当該の都市計画区域では 70年近く人口が飽和しないという計算結果が導き出されている。当 時の都市計画における計画年数は50年が目安とされており、その期 間内に都市計画区域の人口が飽和することはないため、区域の設定 としては妥当である旨の報告がなされている。このように当時の都 市計画区域は計画人口と計画年数を根拠に設定されており、標準的 な一人当たりの面積を算出した上で計画区域の範囲を決定していた ことが確認される。

都市計画島根地方委員会の開催に先だって、事前に都市計画区域 編入に関する意見徵収が行われており、委員会において朗読されて いる。それによれば、法吉村、津田村、乃木村の三ヶ村は異議なく 賛成しているが、川津村は市街化によって耕地が減少することを理 由に反対している。複雑なのは、朝酌村で村全体を区域に組み込む なら異議はないものの、村の一部のみを範囲に組み込むことによっ て施設整備の格差が生じることを懸念して反対している。一方、松 江市からは、遊覧都市として整備するにあたって、景勝地である浜 佐陀川付近まで都市計画区域に含めたらどうかという市会における 議論も報告されている注9）。しかしながら都市計画島根地方委員会に おいて強い反対意見はなく、原案の通り可決し、昭和 5 年 2 月 1 日に計 画決定した。また市街地建築物法の適用範囲も、昭和6年1月1日から 松江駅に近い市外の地域に拡張されることになった。

その後、昭和 14 年 2 月 11 日に川津村、昭和 14 年 11 月1日に朝酌村 が、それぞれ松江市に編入されたのにともない、すべての村域が都 市計画区域に組み込まれることになった。

\section{3. 都市計画街路の策定と事業化}

\section{1 都市計画街路の策定（Fig.1・Tablel）}

松江市の都市計画街路については、昭和7年11月8日に開催された 第三回都市計画島根地方委員会の席上で、議長が「大正十四年頃ヨ リ調査ニ着手致シマシテ県、市及ビ内務省卜再三再四慎重協議ヨ重 ネマシタ結果、今回漸ク成案ヨ得マシタ」注10)と述べているよう に、先述の準備調査以来、県と市、内務省で何度も協議しながら練 り上げられ、最終的には同年12月9日に26路線が計画決定された (Fig.1）。その内訳は一等大路三類1路線（幅員22-28m）、二等大 路一類 2 路線 (幅員 $20 \mathrm{~m})$ 、同二類 8 路線（幅員 $15 \mathrm{~m}$ ) 、同三類 13 路 線 (幅員 $11 \mathrm{~m})$ 、一等小路 2 路線（幅員 $8 \mathrm{~m} ）$ であった。路線数は 「準備調査街路一覧表」の約半数になっており、総延長も $36,790 \mathrm{~m}$ 余に大幅に縮小変更されていることがわかる。とくに一等大路に該
当する広幅員道路の総延長・路線数が大幅に削減されている。ただ し「準備調査街路一覧表」にもとづく計画図は、管見の限り未発見 のため、具体的な路線の変更点は不明である。

計画策定の方針については、幹事の竹内常八（地方技師）からつ ぎのように報告されている。

…ソレデ今回決定セラレントスル此ノ街路計画案ハ松江築港完成ノ暁ヨ考へ マシテ松江駅及松江港附近ヨ交通運輸/ 中心点トシテ、一等大路第三類第一号 幅員十二間ヨ南北二通ジテ主要幹線ト致シマシテ、更ニ之ニ関連致シマシテ二 等大路第一類第一号路線幅員十一間 二等大路第一類第二号路線幅員十一間 7 橋北部二配置致シ、之 致シ、更二之ニ八間線八線ヨ放射状二配置致シマシテ、幹線街路網ヨ確立セシ メ、之等ノ幹線ヨ連結統制スル為二更二十一米（六間）幅ノ道路十三線及ビ四 間幅員 (八米) 二線 7 適当二配置致シマシテ此ノ街路計画案ヨ樹立セラレタル 次第デゴザイマシテ、此ノ道路数ノ合計八二十六線デアリマス、総延長八九里 十二丁四十六間二達スルノデアリマス。

之等ノ路線八現在市街地ノ交通運輸ノ久陷习補フト共二将来市街化ノ趨勢㩆 著ナル東方郊外地、其/他郊外地卜ノ交通ノ幹線ヨ定メラレタモノデアリマシ テ、此ノ計画ニ当リマシテハ街路/屈折八可及的ニ之ヨ避クル方針卜致シ、尚 地勢、特種ノ市街建築物等ノ関係ヨ考慮シタモノデ各路線ノ幅員ハ何レモ将来 ノ交通量其ノ他各種ノ事情习推測シテ之ヨ定メ、詰リ工事費等ノ事 7 考慮致シ マシテ、尚街角八原則的ニ之ヨ剪除スル方針ヨ以テ大綱ヨ決定セラレタモノデ ゴザイマス。

この説明から、松江駅と松江築港に近く、新大橋を通って橋南と 橋北をつなぐ一等大路三類一号線（幅員 $22 \mathrm{~m}$ ) が松江の大動脈とし て位置づけられていたことがわかる。それを軸に二等大路二類一号 線（幅員 11 間）を橋南の、二等大路二類一号線（幅員 11 間）を橋北 の幹線道路とし、二等大路二類8路線（幅員8間）を「放射線状」に 配置するという方針だった。ただし「松江都市計画街路網図」（Fig. 1）から、必ずしも「放射線状」の街路計画になっているわけではな いことがわかる。その上で二等大路三類 13 線と一等小路 2 線を適宜配 置するというものであった。これら都市計画街路は、市街化が顕著 であった東方を含む郊外地の幹線としての役割を担うものであっ た。なお、道路拡幅とともに街路の屈折はできるだけ避ける方針で あり、街角は隅切りを設けるために原則として剪除することで、鍵 曲等の旧城下町の構造を更新しょうとしていたことが確認される。

また、計画決定の理由書に「之等ノ路線八今直二事業トシテ執行 スルハ財政上許ササル所ナル 以テ市街地建築物法ノ運用及土地区画整理ノ施行二備へムトス」注 11）と説明されているように、市街地建築物法の運用と土地区画整理 の基準として計画決定しょうとするものであったことがわかる。こ うした決定理由は、都市計画街路事業を遂行する財政力のない地方 都市で共通している。そして財政に余裕ができた段階で、「路線中 最モ緊急ヨ要スル而モ効果的ノモノタ選ビマシテ都市計画事業トシ テ決定」注12) する方針だったことがわかる。

第三回都市計画島根地方委員会では、休㮩時間を設けて図面をも とに各自質疑を行った後に審議が再開され、鉄道と主要な都市計画 街路との立体交差を考慮するように注文が付けられたものの、原案 通りに決定した。

ここで「交通運輸ノ中心点」として位置づけられた松江港と都市 計画街路との関係についてみておきたい。松江港の築港について昭 和6年12月号の「港湾」注13) では、つぎのように紹介されている。 


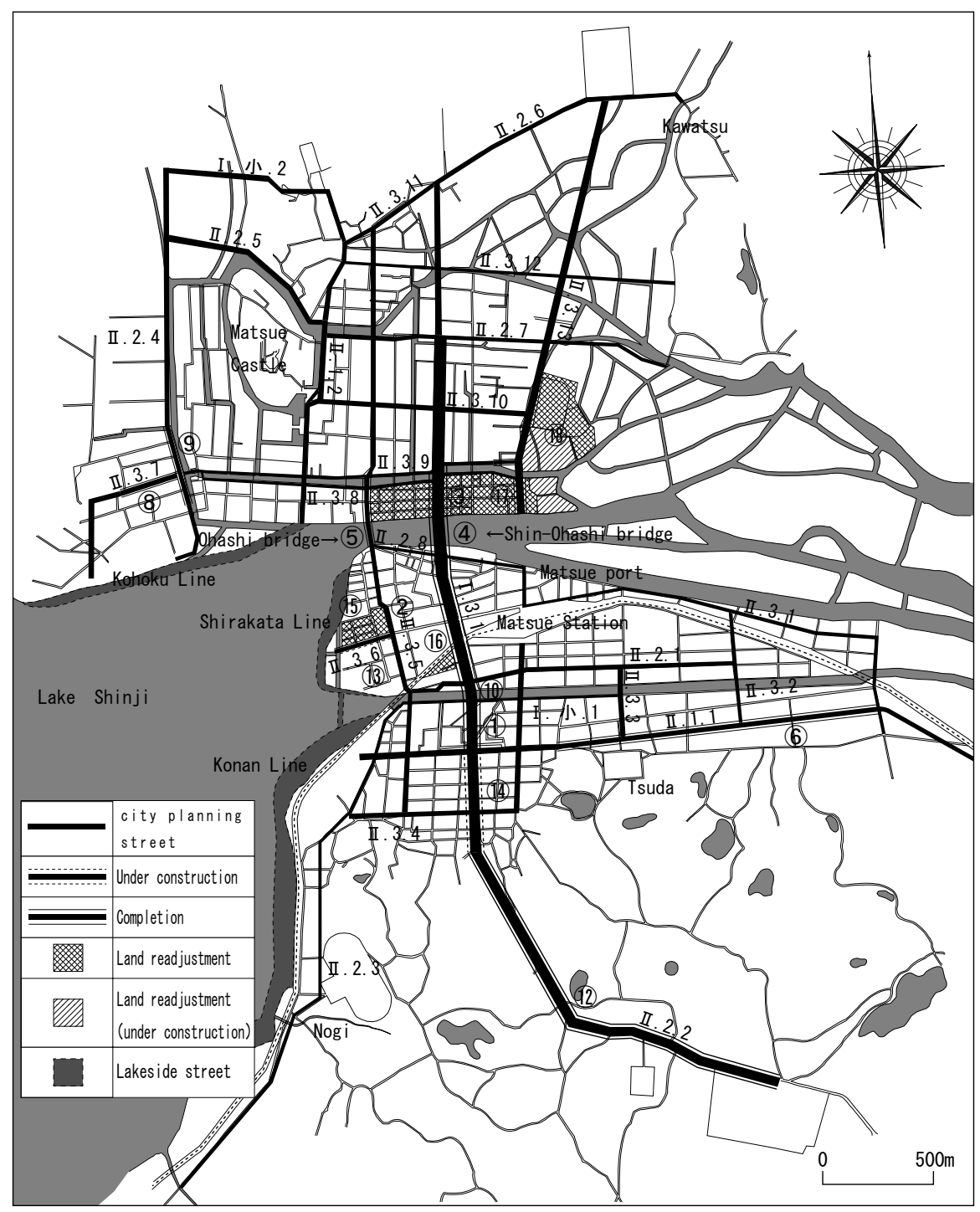

Fig.1 Matsue city planning street map with land readjustment map

"Document of shimane urban planning council, No.3.4.6-10" (Shimane prefectural read division, 1945) in the possession of Shimane prefectural official archive center.

Table2 The rist of urban development project in Matsue (research date 1942.11.15)

\begin{tabular}{|c|c|c|c|c|c|c|c|c|}
\hline Na & city planning & type of project & enforcer & \begin{tabular}{|c|}
$\begin{array}{c}\text { the length of a a } \\
\text { road(m) } / \\
\text { area(Tsubo) }\end{array}$ \\
\end{tabular} & \begin{tabular}{|c|}
$\begin{array}{c}\text { plan of } \\
\text { road } \\
\text { width(m) }\end{array}$ \\
\end{tabular} & \begin{tabular}{|c|} 
the width \\
of a \\
road(m)
\end{tabular} & $\begin{array}{c}\begin{array}{c}\text { working } \\
\text { ecpenses }(Y)\end{array} \\
\end{array}$ & \begin{tabular}{|c|}
$\begin{array}{l}\text { number of city planning street } \\
\text { (grade.class. number) / name of } \\
\text { land readjustment }\end{array}$ \\
\end{tabular} \\
\hline (1) & city planning street & City planning project & Matsue City & 246 & 22 & 22 & 100,000 & 1.3 .1 \\
\hline (2) & city planning street & Road repair & Shimane prefecture & 133 & 11 & 11 & 46,310 & III.3.5 \\
\hline (3) & city planning street & Road repair & Shimane prefecture & 212 & 22 & 22 & 73,455 & 1.3 .1 \\
\hline (4) & city planning street & Bridge-building & Ministry of Home Affairs & 140 & 22 & 13 & 360,000 & 1.3 .1 \\
\hline (5) & city planning street & Bridge-building & Shimane prefecture & 134 & 11 & 12 & 360,000 & III.3.5 \\
\hline (6) & \begin{tabular}{|c|} 
city planning street \\
\end{tabular} & Route improvement & Ministry of Home Affairs & 1,514 & 20 & 15 & 87,000 & III.1.1 \\
\hline (7) & city planning street & Fire reconstruction & Matsue City & 387 & 11 & 11 & 28,490 & III.3.5, II.3.9, Шा.3.13 \\
\hline$(8)$ & $\begin{array}{l}\text { city planning street } \\
\end{array}$ & Fire reconstruction & Matsue City & 180 & 11 & 11 & 9,810 & III.3.7 \\
\hline (9) & city planning street & Fire reconstruction & Matsue City & 410 & 15 & 15 & 46,481 & II. 2.4 \\
\hline (10) & city planning street & Bridge-building & Shimane prefecture & 28 & 22 & 14 & 29,366 & 1.3 .1 \\
\hline (II) & \begin{tabular}{|c|} 
city planning street \\
\end{tabular} & Route improvement & Ministry of Home Affairs & 887 & 22 & 13-16 & 59,800 & I.3.11 (pavement) \\
\hline (12) & city planning street & Road repair & Shimane prefecture & 2,056 & 15 & 10 & 172,385 & III. 2.2 \\
\hline (3) & \begin{tabular}{|c|} 
city planning street \\
\end{tabular} & City planning project & Matsue City & 296 & 11 & 11 & 72,400 & \begin{tabular}{|l|} 
II. 3.6 (under construction) \\
\end{tabular} \\
\hline (4) & city planning street & Road repair & Shimane prefecture & 361 & 15 & 15 & 345,000 & II. 2.2 (under construction) \\
\hline (15) & Land readjustment & Fire reconstruction & Land readjuntment union & 3,872 (Tsubo) & & & 6,601 & 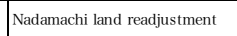 \\
\hline$(6)$ & Land readjustment & Fire reconstruction & cooperative association & 3,714(Tsubo) & & & 3,155 & Teramachi land readjustment \\
\hline (18) & Land readjustment & Fire reconstruction & Land readjuntment union & 39,587 (Tsubo) & & & 385,887 & Syoto land readjustment \\
\hline 8 & Land readjustment & Lebel the ground & Land readjuntment union & 43,361(Tsubo) & & & 42,255 & \begin{tabular}{|l}
$\begin{array}{l}\text { Mukoujima land readjustment } \\
\text { (under construcion) }\end{array}$ \\
\end{tabular} \\
\hline
\end{tabular}

"Document of shimane urban planning council, No.3.4.6-10" (Shimane prefectural read division, 1945) in the possession of Shimane prefectural official archive center. (1) (18) : the same as Fig.1 number.
・また荷揚場裏側に四間道路を新設するほか大橋川 沿ひに御手船場町から松江駅へ通ずる幅員二間の道路 を築設して海陸の連絡をますます緊密にし貨物運輸の 円滑を期することになつた、なほ都市計画道路網の決 定に伴つて市民から要望されてるる大橋北詰から大橋 川に沿うて築港に達する幅員六間の道路も財政が許せ ばなるべく早く完成せしめる方針である。

第三回都市計画島根地方委員会が開催される 約一年前の資料であるが、御手船場から松江駅 に通じる幅員2間の道路、荷揚場裏側の4間道路 を新設し、さらに大橋北詰から大橋川に沿って 松江築港に達する幅員6間の道路も都市計画街路 の決定にともなって財政が許す限り整備される 方針だったことがわかる。これらは松江大橋か ら一等大路三類一号線と交差し、松江駅前に通 じる都市計画街路（二等大路二類八号線）に該 当しており、幅員11-15mの街路として整備され る方針だったが、戦前の時点で拡幅されること はなかった。

\section{2 都市計画街路の事業化（Table1）}

さて、昭和8年9月18日に、都市計画街路の事 業化に向けて第四回都市計画島根地方員会が開 催された。このとき議題として取り上げられた のは旧国道19号線に該当し、松江でもっとも広 幅員（車道幅員 $16 \mathrm{~m}$ 、歩道各 $3 \mathrm{~m}$ ) だった一等大 路三類一号線の一部を整備する事業であった。 これは産業開発と交通機関の統制を目的とし、 新大橋の架け替えにあわせて、雑賀町から天神 川右岸に至る延長 $246 \mathrm{~m}$ （幅員 $22 \mathrm{~m}$ ） を整備し ようとするもので、松江における道路計画の根 幹となる事業として位置づけられていた注14)。

当初、総工費は約 18 万円と見積もられており注 15)、事業主体となる松江市は国庫補助の審査を 受けていた。すでに指摘されるように、国道・ 府県道に該当する都市計画事業に対してはじめ て国庫補助が導入されたのが昭和 8 年度からであ り 注16)、松江市も最初に交付を受けた19都市の 内の一つに該当している。『都市公論』注17）に はつぎのように記されている。

\section{都計道路補助金交付都市決定}

内務省都市計画課では昭和八年度において中小都市が 産業振興、時局匡救事業によつて改良せられた道路、港 湾等と都心とを連絡する国道、府県道の改良工事を都市 計画事業として執行する場合は国庫補助金を交付するこ とになつたので、過般来これが補助総額四十八万円の地 方公共団体割当につき審査中であつたが、六月一日左の 十九都市を決定、六月中に執行箇所の調查を完了し補助 金交付の指令を発することになつた（対象都市省略） 
このことから、中小都市の産業振興、時局匡救事業によって改良 された道路や港湾等と連絡する国道、府県道の改良工事を都市計画 事業として実施する場合に国庫補助が交付されることになってお り、松江市の一等大路三類一号線も、産業開発の一環として整備さ れた松江港附近で架け替えられることになった新大橋と連絡する国 道であったことから交付対象になったことがわかる。

国庫補助の交付を受けて一等大路三類一号線の事業化について第 四回都市計画島根地方委員会で審議されることになったが、そこで 議論されたのが財源であった。というのも竹内幹事の説明を以下に 抜粋する通り注18)、戦前の都市計画において一般的に用いられてい た受益者負担ではなく、公債を財源とする方針だったからである。

…受益者負担金ヨ課セナイト言つ理由八、本事業ガ時局匡救事業ニ準ズル事 業デアルト云フコトト且ツ新大橋改架卜関連致シマシテ緊急執行ヨ要シマシテ 昭和八年度二於テ是非完成セシムベキモノト云フコトニ起因スルモノデアリマ シテ、且又之ノ規定二基ク負担金ヨ謹少区間二課スル八附近地ノ商工業ガ目下 尚余リニ不振デアルコトト、街路開設後二於ケル附近地ノ土地利用価值増進, 程度ガ、極メテ謹少デアルト推測セラレタ結果卜、察知スル次第デゴザイマ ス。次二天神川ニ架スベキ橋梁二付キマシテハ、今回/事業計画二包含セラレ テキナイノデアリマスガ、此八本件事業促進卜共ニ何ラカノ方法ヨ講ジマシ テ、計画セラルベキモノト信ズルノデアリマス。本件都市計画事業八新大橋改 架天神川橋梁計画等ノ実施卜相俟ツテ、産業開発二資スルトコロ甚大ナルノミ ナラズ、交通運輸機関二一新機軸ヨ招来致シマシテ、松江市将来/大計二寄与 スベキ重大案件デゴザイマス。…

この説明から、昭和恐慌の救済措置として各地で実施されていた 時局匡救事業に準じるかたちで計画されていたことがわかる。そこ で新大橋の架け替えにあわせて、産業開発に効果があり、交通の基 幹となる都市計画街路を整備する計画であり、緊急かつ将来的に重 要な街路が選ばれた。ただし附近の商工業が不振であり、土地利用 の増進が限られているという判断から、受益者負担を課さない方針 だったことがわかる。これに対し、内務技師の坂本助太郎は次のよ うに質問している。

都市計画事業ノ財源ノ一部トシテ受益者負担金ヨ一般ニ充テ >オルノデアリ マス。然ルニ当事業ニ限ツテ受益者負担金习課セナイト云フコトハ若シ此ガ先 例卜ナレバ、将来都市計画事業施行上一大障害トナルデハナイカト思ヒマス。 其レハ四番二伺ヒタイノデアリマス。受益者負担金ヨ課セザル本事業ハ先例卜 ナル処ハナイノデアリマスカ。斯ウ云フコトヨ伺ツテ見タイト思ヒマス。

このことから、内務省としては、当時、都市計画事業の財源は受 益者負担金によるのが一般的であり、この事業で例外的に受益者に 負担を課さないとなると、その後の事業費の確保に大きな障害とな ることを懸念していたことがわかる。それに対し、答弁を求められ た松江市長の石倉俊寛（四番）はつぎのように答弁している注19)。

私カラオ答へ致シマス。之ノ都市計画事業ヨ実施スルニ当リマシテ案画致シ マシタ当初、……番ノ御質問ノアリマシタ通リ全ク受益者負担ヨ課セナイト 云フコトハ不合理ノヤウニ考へマシタノデアリマスガ、然シ先程竹内幹事カラ 委シク御説明ガアリマシタヤウナ状況デ、大体之ノ事業ヨ実施スルニ当ツテ、 新大橋ノ改架ト云フコトヨ行ツタ為二、是非交通系統カラ之ノ道路习構築セネ バ新大橋改架ハ容易二実現セナイト云フ関係モアリ、更二本年度ノ事業トシテ 之ノ道路 構築セネバナラヌト云フヤウナ点ナリ 二負担ヨ掛ルト云フコトハ容易二出来難イノミナラズ、従来規定ヨ設ケテオリ
マス其ノ規定ニ依テ三分ノ一ヨ定メレバ、負担シ切レナイト云フヤウナ関係ヨ 持チマシテ、受益者負担ヨ掛ケナイト云フコトニ致シマシタノデアリマス。

今後都市計画法ニ依リマシテ実施致シマス場合ニハ此ノ分ヨ先例卜致シマセ ンデ、将来八負担規定ヨ設ケ其レニ基イテ受益者ノ負担二依テ事業ヨ施行致シ タイト思ヒマス（後略）

この答弁から、当初、松江市側も都市計画事業の実施にあたって 受益者負担を検討していたことがわかる。しかし本年度に新大橋の 架け替えるのにあわせて、そこに接続する当該道路の整備をせざる を得ないこと、昭和恐慌下において沿道住民に負担をかけることが できないという点から、松江市では受益者負担を徵収せずに整備す る方針を固めた。ただし、あくまでも特例であり、今後の都市計画 事業においては受益者負担によって事業化すると説明している。こ うして一等大路三類一号線の事業化は原案の通り可決され、10月2日 に決定、同10月12日に告示された。総事業費は10万円であり、国庫 補助 2 万円、残額を県と市で負担することになり、昭和 8 年度中に整 備が完了した。

松江の大動脈である一等大路三類の都市計画事業はわずか $246 \mathrm{~m}$ と 部分的だったが、国道に該当する路線だったこともあり、内務省に よって新大橋が事業費36万円で架け替えられたほか、舗装工事が行 われている。一方、県でも松東の火災復興土地区画整理にあわせて 道路改良と天神川の架橋を行っている（Table2）。

つぎに、松江の都市計画街路事業が事業決定するのは、二等大路 三類六号線であり、昭和12年7月26日に開催された第六回都市計画島 根地方委員会で審議された。二等大路三類六号線は、松江の中心市 街地と、白潟埋立地先の松江水上飛行場（定期航空大阪松江線）を 連絡する重要な道路であったが、既存の市道の幅員が $5 \mathrm{~m}$ と狭小で交 通上不便であったこと、白潟遊園地で翌年度に神国大博覧会が開催 予定だったことから、昭和 12 年度中の事業化が計画された。具体的 な事業内容は、総工費72,400円（主な事業費目：用地13,498円、移 転費23,154円、道路築造費14,316円、舗装費6,205円、橋梁費8,800 円、事務費3,999円ほか) で、延長296m を幅員 $11 \mathrm{~m}$ に拡幅し、白潟 埋立地に橋梁を新設しょうとするものであった。

このとき議論の焦点になったのは、二等大路三類六号線の都市計 画街路がわずかに曲がっている点であった。将来的に直線的な街路 整備ができるように道路の方向性のみを決定し、拘束力が生じる詳 細な線引きを行わないようにしたらどうかという意見も出されてい たが、建築規制をともなう都市計画街路の性格上、線引きをせざる を得ないことが補足説明され、直線化にあたって用地買収が嵩むと いう工費の点、博覧会までに間に合わせるという工期の点から最終 的には原案の通りに可決された。この街路事業の財源は、市債とと もに先述の受益者負担金が徵収されることになり、同委員会では 「松江都市計画事業道路新設拡築受益者負担二関スル件」の審議も あわせて行われた。受益者負担制度は内務省令にもとづいており、 各都市で定めた条文の内容はほとんど同じだったとされるが、受益 者負担の範囲と割合については若干の相違があった。松江市では負 担の範囲を道路幅の五倍とし、負担額は道路新設の場合で $1 / 3$ 、道路 拡幅の場合で $1 / 4$ とされたが、それは当時の負担割合としては一般的 な内容だったという注20)。このころ松江では火災がくり返し発生し ており、火災復興のたびに受益者負担が掛かることを懸念し、市長 
が緩和措置を取れるようにするといつた意見も出されたが、最終的 には条文に付け加えられることなく、原案の通りに可決した。

つづいて、第七回都市計画島根地方委員会では、都市計画街路の 変更と事業執行年度変更の審議が行われた。街路変更は、昭和 12 年 4 月に中原町で大火が発生し、区画整理を施行する関係で二等大路二 類四号線の位置を $2 \mathrm{~m}$ 西側に移動するというものであった。大火の際 に四十間堀川が延焼防止の役に立ったことから、防火線として機能 させるために、堀川にかかっていた都市計画街路を移動するもので あり、防火という観点から異議なく可決した。一方の事業執行年度 変更については、先にみた二等大路三類六号線の用地買収が、日中 戦争の影響で捗らず、また神国大博覧会も延期されたことから、昭 和12-13年度継続事業に変更された。けれぞも、この街路整備は難航 し、第八回都市計画島根地方委員会でも事業年度割の変更が審議さ れ、物価高騰のため、事業を中止するか否かの審議が行われたが、 すでに半数以上の土地所有者の買収が進められていたことから、昭 和14-15年度の二力年継続事業として実施することが決定された。さ らに第十回都市計画島根地方委員会では、昭和12-15年度の間に3割3 分4厘しか完成できなかったことから、昭和16-18年度に事業執行年 度割を延長することを計画決定した。

このようにくり返し事業を延長したものの事業を完遂することは できず、昭和 19 年 6 月 10 日に開催された第 12 回都市計画島根地方委 員会において二等大路三類六号線の廃止が審議され、同年7月7日に 告示された。その際の理由書にはつぎのように記されている注21)。

本路線八松江駅ヨリ神国博覧会々場ノ予定地夕ル白潟埋立地二到儿都市計画 事業路線トシテ昭和十二年ヨリ松江市二於テ事業執行中ナリシモ時局ノ進展二 伴七神国博覽会/開催無期延期トナリ為メ二事業執行モ予期ノ進捗 $コ$ 見ヅ三度 二亘り執行年度 7 延長セシモ遂二本年三月末日 ノ都市計画戦時特例ニ拠り事業廃止セムトスルモノナリ

この史料から都市計画戦時特例にもとづき都市計画事業を廃止し たことがわかる。なお、ここまでの工事の進捗は「橋梁工事完成， 外一部用地買収及物件移転习了セルモ全工事ノ三十五\% $\%$ 進メ夕ル 二過キス」注22）とあることから、橋梁と全工事区間の $35 \%$ が完了し たにとどまったことがわかる。また同時に、二等大路第三類一号 線、同二号線の変更も決定された。その理由書にはつぎのように記 されている注23)。

本路線ノ沿線一帯八時局ノ要請二基キ急速二工場地帯ノ造成セラレッッアル 所ニシテ殊二広範囲ノ地域 擁スル三井木船建造株式会社松江造舩所ノ設置ス ル所トナリ為二既定計画街路路線ノ一部习南方ニ移動セシメ以テ工場機能ノ阻 害ヨ避クルト共二戦時下二即応スル都市計画事業ノ合理化ヨ計ラムトスルニア リ

戦時下において軍需工場用地を造成するために、既存の都市計画街 路を工場の機能を阻害しないように変更しており、当時の地方の都 市計画においても戦争の影響が確かに及んでいたことが窺える。

\section{3 松江市の道路整備（Fig.1・Table2）}

「都市計画区域内事業調」（昭和17年11月15日現在調）を整理し たのが、Fig.1 とTable2の(1)〜18である。先述の通り、松江市におけ る都市計画街路事業は(1) と (13)の2路線だけであり、(13)は中断を余儀な くされた。一方、内務省が施工した国道改良事業は(6)(11)島根県が
施工した局部改良は(2)(3)(12)(14が該当しており、都市計画街路の道路 改修や舗装などが一定度行われたことが確認される。その中心にな っているのが、現在の松江の大動脈となっている新大橋をはさむ南 北の幹線道路（一等大路三類一号線(1)(3) とその延長線（二等大路 二類二号線 (12) (14)）であり、橋梁の改築も含めて整備された (4)(10)）。また近世以来の中心軸であった松江大橋をはさむ南北線 (二等大路三類五号線(2)(5)(7) でも道路改修や橋梁の改築が行われ ていることが確認される。また火災復興にともない、道路整備 (7)89) や区画整理（15)(16)(17) が行われており、他の地方都市と 同様、市街地整備の契機となっていたことがわかる。

\section{4. 未決定の都市計画}

(1)湖岸道路 : 宾道湖の湖岸道路は、観光都市松江における一大事業 であり、先述の都市計画準備調査の一環で計画され、大正14年3月30 日に開催された都市計画準備調査委員会の総会において大綱が決定 した。石倉俊寛市長の「湖岸道路問題に就て」注24)によれば、松江 市はつぎの意向を持っていたことがわかる。

……今や伯備線は開通し近き将来には大社宮島線の開通を見んとし又松江港、 恵曇港修築竣成の期も近づき殊に松江と神都大社とを結ぶ一烟電鉄は日に十数 回の直通電車を通はして居る様な次第で時世は将に刻々と変化しつ> あるので ありまして水郷都市、遊覧都市としての特色を発揮すべき施設につき時代は将 に之を促して居るのであります、各般の施設に於て遅れ勝ちな我が市に於ても 遊覽都市としての対策に付計画を樹つるは最も肝要であります、又一面、時恰 かも内務当局に置かれては斐伊川改修事業に伴ひ宾道湖の航路浚渫をせらる 予定で、是によりて多量の残土が出ますから之を埋立工事に利用することが出 来るので此の埋立の出願をするには今が千載一遇の好機会でありまして、他日 如何に好景気となり財源がありましても埋立の免許がなければ事業は出来ない のでありますから今此の埋立出願をすることは最も機宜に適したるものと信じ ます

この記述から昭和5年当時、伯備線の敷設や松江港の竣工、一畑電 鉄の開設により、水郷都市、遊覧都市として特色を発揮する土壌が 整いつつあったことが窅える。一方、斐伊川改修事業にともなう穴 道湖の浚渫によって大量の残土が発生したことから、それを埋立工 事に利用することで湖岸道路の整備を進める絶好の機会としてとら えていたことがわかる。そして昭和4年10月以降、詳細な調査研究を 行った結果、以下の計画を想定していたことが、前揭の「湖岸道路 問題に就て」からわかる。

一、湖岸道路として新設せんとする位置は湖北線法吉村大字国屋天倫寺鼻より 松江大橋に至る八百九十九間、白潟線松江大橋より白潟天満宮裏新設橋南 詰に至る五百二十三間、湖南線幸町北端より乃木村大字福留半原橋に至る 一千三百七十八間、合計延長二千八百間、内橋梁五ヶ所延長百二十五間で あります

二、道路幅員は大体二十間とし外側七間を植樹地帯となし、次に幅六間の車道 を設け而して幅五間の芝生園を置き、更に幅二間の歩道を画するのであり ます、湖北線大橋より西約百間、白潟線大橋より西南約七十間、湖南線半 原橋より湖岸に至る約百間の部分は歩車道のみ構築する計画です

三、埋立出願面積は六万八千七十一坪にして同時に埋立つへき民有水面二千百 八十二坪を有するが故に埋立総面積七万二百五十三坪なのであります。而 して此の中道路敷地に供用すべき面積は四万二千六百七十坪とし他は余㮃 地であります 
四、埋立に要する土量の一部は内務省斐伊川改修事業中に含まれをる宍道湖浚 渫土砂を利用し、不足土量は可成其の附近に於て湖底を浚渫し之に供する のであります

五、之に要する総工費は八十万円であります

六、末次埋立地八千百八十八坪中六千坪、金二十四万円を以て売却し資金に充 当し、残高五十六万円は工事の進捗に伴ひ余剩として生ずべき二万七千五 百八十三坪を売却して支弁するのでありまして、工事終了せば、金三万八 千百六十五円に相当する土地を余す計算であります

この史料から、湖岸道路計画では、湖北線（899間）、白潟線 （523間）、湖南線（1,378間）の三線が計画されていたことがわか る。道路幅員はおよそ20間とし、その内訳は一部区間を除いて、湖 岸から幅7間を植樹地帯、幅6間の車道、幅5間を芝生公園、幅2間の 歩道を設けることを想定していた。埋立総面積は70,253坪であり、 その内、道路敷地は42,670坪の予定で、のこりは余剩地として売却 することで事業費を捻出する方針だった。埋立の土壤は内務省の斐 伊川改修事業の一環として行わ扎る宾道湖浚渫土砂を利用し、不足 分はできるだけ事業力所周辺の湖底を浚渫することで調達する算段 だった。事業費は総工費80万円と算出しており、事業計画は第一期 から第四期の10ケ年を想定していた。具体的には、末次埋立地のあ る湖北線から順次湖南線にかけて事業を実施する計画であり、いず れも埋立事業と道路整備を一体的に行い、沿道の余った土地を売却 して事業費を捻出する方針だった注25)。このように余剩地の売却利 益によって事業費をまかなうという計画手法は、国内で制度化され つつも、ほとんど使わ机なかった超過収容の考え方に近いものであ つたといえる。

ところで、宾道湖の湖岸道路は、昭和 12 年に作成された「松江都 市計画図」にも図示されているように、市街地整備の観点から一体 的に考慮されていたと推測されるが、法定の都市計画街路として計 画決定されることはなかった。その理由は、湖岸道路が埋立事業と 一体的に整備される計画だったことから、公有水面埋立法にもとづ く事業として位置づけられていたからだと考えられる。

さて実際の事業化に関しては、県が難色を示したため、着工は一 年延期になったが、継続した運動が功を奏し、内務省に 20 年継続事 業として条件付きで認可されることになり、昭和七年三月に起工式 が行われた。「山陰新聞」（昭和6年5月20日付）によれば、具体的 な条件は、(1)着工は財源確定後とする、(2)湖岸の風致を破損しない 施設にすること、(3)一線が完成しなければ、他線に着手しないこ と、(4)道路をを国有に寄付すること、(5)埋立法に従うこと、(6)実施 設計はその都度、県の承認を受けることであった。実際には、(1)の 条件を満たすことは困 難であり、戦前の時点 では、失業救済事業と して一部が整備される にとどまった注26)。

(2)用途地域 : 松江市に 用途地域が導入される のは、昭和32年1月の ことだが、調査自体は 昭和 13 年前後に「松 江都市計画地域」につ いて検討されており、

Table3 Zoning plan in Matsue before W.W.II

\begin{tabular}{|c|c|c|c|c|}
\hline \multirow[t]{2}{*}{ Zoning } & \multicolumn{2}{|c|}{$\begin{array}{l}\text { preparatory city } \\
\text { planning survey }\end{array}$} & \multicolumn{2}{|c|}{$\begin{array}{l}\text { Zoning of Matsue } \\
\text { proposed city plan }\end{array}$} \\
\hline & area(tsubo) & $\%$ & area(tsubo) & $\%$ \\
\hline Residencial area & $1,557,000$ & 39.4 & $2,477,500$ & 74.3 \\
\hline Commercial area & 442,000 & 11.2 & 453,100 & 13.6 \\
\hline Industrial area & 245,000 & 6.2 & 376,000 & 11.3 \\
\hline Unspecified area & 449,000 & 11.4 & 28,100 & 0.8 \\
\hline Park district & 318,000 & 8.1 & & \\
\hline Scecic district & 100,000 & 2.5 & & \\
\hline Mountains etc & 837,323 & 21.2 & & \\
\hline Total & 3,948,323 & 100.0 & $3,334,700$ & 100.0 \\
\hline
\end{tabular}

以下の文書が作成されている注27)。

……本市ノ地域ニ付按スルニ現在商業ノ最モ殷盛ナルハ市ノ南北幹線タル大 橋筋通り卜東西幹線ノ本町、未次町通り及松江駅ノ東西通リ二沿つ市ノ中心地 ニシテ利便ナル地区ヨ之ヨ商業地域二定メ、所謂、橋北即千大橋川以北及天神 川以南/高燥且緑地二富么健康保健地八住居地域卜シ恒風ノ関係及交通運輸上 ヨリ尤モ至便/位置ヨ占ムル大橋川下流部天神川ニヨリ囲繞セラル > 松江駅以 東区域ヨ以テ工業地域二指定シ将来/発達ヨ遂ケシムル八適当ナリト信ス、此 ノ外、駅裏ノ一部片倉製糸工場二至ル区間八工業地域二於テ発散スル煤煙、臭 気、其他燥音ノ緩衝地帯トシテ未指定地区二保留シタリ、尚大橋川以北川津村 及朝酌村ノ市二接続スル耕地八灌溉用水其他卜ノ関係上之レ 7 現存ノ侭永久二 緑地トシテ保存セムトスル方針ナリ

この史料から、松江市では白潟本町を中心栄えた南北幹線の大橋 筋、松東土地区画整理で整備された東西幹線（現東本町、東茶屋 町、末次町とつづく商店街）、松江駅前の東西道路の中心市街地を 商業地域として想定していたことがわかる。一方、大橋川以北と天 神川以南の旧武家地の一帯を住居地域に設定していた。また大橋川 下流で天神川と囲われた水運の発達する地区を工業地域にする予定 であった。また市の北東部に位置する川津村、朝酌村に接続する耕 地は灌溉用水その他との関係から緑地として保存する方針だったこ とがわかる。

先述の「都市計画準備調査」と比較すると商業地域の面積があま り変わっていないのに対し、住居地域が92万坪余も増加しているこ とがわかる（Table3）。その一方で未指定地域が大幅に削減されて いるほか、風致地区も設定されていない。工業地域は13万坪余り増 加している。「都市計画準備調査」では具体的な地域が設定されて いなことから単純に比較はできないが、それぞれの面積からは必ず しも「都市計画準備調査」を踏襲しているわけではないことが想定 される。

松江市では、戦前の時点において用途地域の導入に向けた詳細な 調査が少なくとも2度実施されていたことが確認されるが、実際に計 画決定されることはなかった。おそらく市街化が顕著ではなかった ことが要因だと推察されるが、実際に都市計画島根地方委員会の席 上で議論された記録は管見の限りでは確認されない。

\section{5. 土地区画整理事業}

\section{1 松江における耕地整理・土地区画整理}

松江市では、法定都市計画の適用前の大正15年11月に旧津田村と 連合で耕地整理組合を設立している。この耕地整理では、斐伊川改 修工事の一環として大橋川を浚渫し、そこで発生した土砂を使って 浸水に悩まされていた駅南東部の水田一帯を嵪上げする計画であ

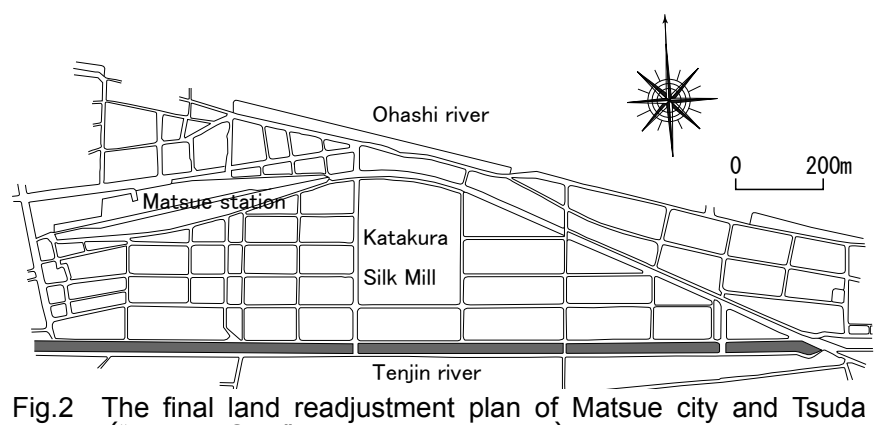
village ("Kukaku Seiri" vol.2-8, p.44, 1936.8) (traced map) 
Table4 Land readjustment in Matsue before W.W.II

\begin{tabular}{c|c|c|c|c|c|c|c}
$\begin{array}{c}\text { District } \\
\text { name }\end{array}$ & $\begin{array}{c}\text { area } \\
\text { (Tsubo) }\end{array}$ & $\begin{array}{c}\text { working } \\
\text { ecpense } \\
\text { (¥) }\end{array}$ & $\begin{array}{c}\text { approval } \\
\text { date }\end{array}$ & $\begin{array}{c}\text { constructio } \\
\mathrm{n} \text { date }\end{array}$ & $\begin{array}{c}\text { completio } \\
\mathrm{n} \text { date }\end{array}$ & enforcer & outline \\
\hline Nadamachi & 3,872 & 6,601 & 1929.1 & 1929.3 & 1931.8 & $\begin{array}{c}\text { Land readjuntment } \\
\text { union }\end{array}$ & $\begin{array}{c}\text { Fire } \\
\text { reconstruction }\end{array}$ \\
\hline Teramachi & 3,714 & 3,155 & 1930.5 & 1930.9 & 1931.6 & $\begin{array}{c}\text { Cooperative } \\
\text { association }\end{array}$ & $\begin{array}{c}\text { Fire } \\
\text { reconstruction }\end{array}$ \\
\hline Mukoujima & 43,361 & 42,255 & 1930.11 & 1931.4 & - & $\begin{array}{c}\text { Land readjuntment } \\
\text { union }\end{array}$ & Lebel the ground \\
\hline Syoutou & 39,587 & 385,887 & 1932.5 & 1932.7 & 1941.1 & $\begin{array}{c}\text { Land readjuntment } \\
\text { union }\end{array}$ & $\begin{array}{c}\text { Fire } \\
\text { reconstruction }\end{array}$ \\
\hline
\end{tabular}

Table5 Area ratio befor and after Shoutou land readjustment project

\begin{tabular}{|c|c|c|c|c|c|}
\hline & geography & $\begin{array}{c}\text { area befor land } \\
\text { readjustment } \\
\text { (Tsubo) }\end{array}$ & $\begin{array}{l}\text { area } \\
\text { ratio } \\
(\%)\end{array}$ & $\begin{array}{l}\text { area after land } \\
\text { readjustment } \\
\text { (Tsubo) }\end{array}$ & $\begin{array}{c}\text { area } \\
\text { rario } \\
(\%)\end{array}$ \\
\hline \multirow{8}{*}{$\begin{array}{l}\vec{z} \\
\frac{\vec{z}}{\tilde{g}} \\
\vec{z} \\
\vec{z}\end{array}$} & rice field & $5,567.00$ & 14.0 & 738.00 & 2.0 \\
\hline & field & $1,758.00$ & 5.0 & & \\
\hline & residential land & $22,880.44$ & 59.0 & $27,062.15$ & 70.0 \\
\hline & miscellaneous & 69.00 & & & \\
\hline & private load & 296.00 & 1.0 & & \\
\hline & pond & 3.00 & & & \\
\hline & on the water & $3,585.61$ & 9.0 & & \\
\hline & total & $34,159.05$ & 88.0 & $27,800.15$ & 72.0 \\
\hline \multirow{5}{*}{ 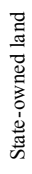 } & river & 64.28 & & 584.94 & 2.0 \\
\hline & ditch & 745.20 & 2.0 & & \\
\hline & street & $3,540.50$ & 9.0 & $10,102.31$ & 26.0 \\
\hline & bank & 508.46 & 1.0 & 94.80 & \\
\hline & total & $4,858.44$ & 12.0 & $10,782.06$ & 28.0 \\
\hline & total & $39,017.49$ & 100.0 & $38,582.06$ & 100.0 \\
\hline
\end{tabular}

"Chiseki"(Shimane prefectural civil engineering section 1932)in the possession of Shimane prefectural official archive center. There is an error of 0.15 tsubo after land readjustment.

り、第一区を松江（事業費32,853円余）、第二区を旧津田村（事業 費85,684円余）に分割して施行され、昭和8年8月末日に完了した。 耕地整理による事業であったが、実質的には土地区画整理による市 街地整備であり、松江停車場に近いことから駅の南側と東側は次第 に宅地化していた（Fig.2）。また片倉製糸会社や日本発送電会社火 力発電所等の企業が立地したことから、市内随一の工業地へと変容 していった。

一方、法定都市計画にもとづく土地区画整理は、Table4に示すよ うに、灘町、寺町、向島、松東の4地区で施行された。灘町の土地区 画整理は、先述の通り、昭和2年12月に発生した火災復興として計画 された（Fig.1-15）。松江市は専任職員を増員して事業の指導を行う とともに、道路工事費のすべてを負担した結果、組合の負担は土地 の無償提供と事務費1,900円のみであった注28)。また灘町の火災は周 辺一帯にも延焼したことから、罹災した寺町でも共同施行の土地区 画整理が施行されることになった（同-16)。その後、松江市では毎

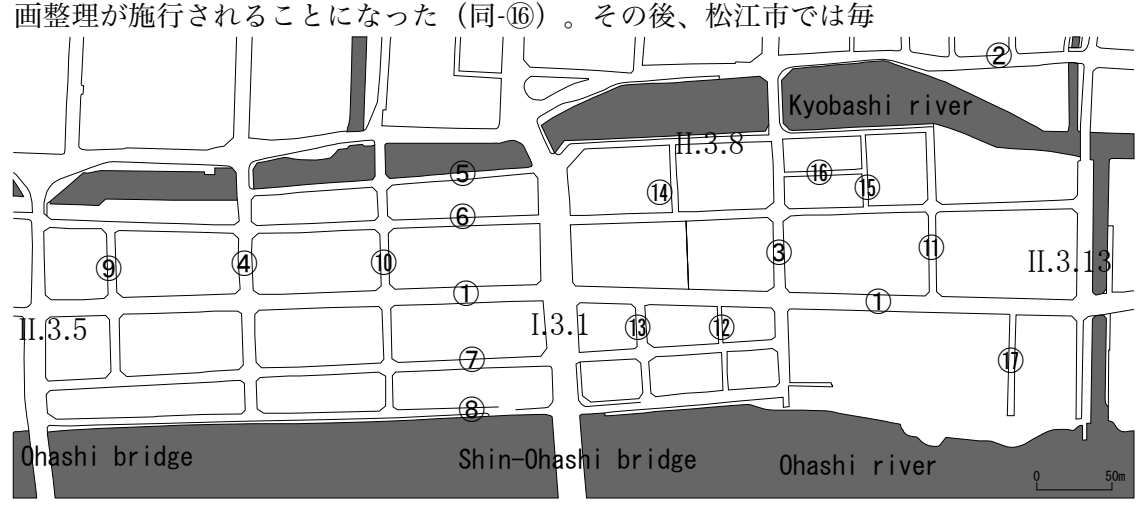

Fig.3 Shoto land readjustment plan (traced original old map) in the possession of Shimane prefectural official archive center.
年度経費を計上して土地区画整理の啓蒙を行っており、とりわけ市 外北東の郊外において地主たちにその必要性について勧奨したとい う。向島では、市営瓦斯工場や公設運動場（松江運動場・松江野球 場）の計画とあわせて区画整理による郊外開発が開始された（同(18)）。また松江市は、とくに市街地整備の必要性の高い地域におい ては、都市計画事業として市が施行する意向を持っていたようであ るが注29）、戦前の時点で公共団体施行土地区画整理は計画決定され ていない。次節では、戦前松江市最大の土地区画整理だった松東地 区については述べることにする（同-17）。

\section{2 松東の土地区画整理事業}

昭和6年5月 16 日午後三時半頃、末次町の旅館から出火し、大橋川 筋、新材木町、漁師町、御舟屋町、末次魚町、鍛冶町、紙屋町、向 島町の大部分に延焼し、総戸数650戸が焼失した。5月18日には、大 火復興に向けた協議のために緊急で市会が開催されている。市会で は、まだ未決定のため予定線だったが、一等大路三類一号線に該当 する南北幹線道路（幅員八間乃至八間二分）、京店から向島まで通 じる六間道路、大橋北口から新大橋までの四間道路の整備は異論な く、東西道路を三本にするか四本にするかの議論が分かれたため、 現地調査を実施することになった注 30$) 。 そ の$ 結果、当初、京橋川は 都市計画に関連して埋め立てる予定だったが、延焼を防ぐのに一定 の役割を果たしたことから、幅十間くらいに狭めた上で浚渫し、温 存する方針に変更した。南北線の幹線道路は十間乃至十二間の広幅 員街路とし、東西の幹線道路は京橋川沿いに変更することになり、 二等大路三類八号線予定線（十間乃至十二間）として整備されるこ とになった。この二路線を基軸とし、罹災地区内に東西線と南北線 を配置することになったが、議論がまとまらなかったため、松江都 市計画の顧問だった内山新之助（大阪市都市計画課長）の意見を参 照することになった。

内山は火災の一報を受け、5月19日の始発で松江市役所を訪れ、土 木課で打ち合わせた後に現地視察を行った。内山の復興に向けた見 解は概ね松江市と一致していたが、東西道路は3路線とする提案して いる注31）。しかし従前の表通りに面する商店の間口の総延長が1,200 間だったのが、700間に削減されることになるため、松江市は内山に 再設計を依頼している。この再設計案については、5月20日に開催さ れた市会において審議され、白熱した議論が繰り広げられたようで あるが、最終的に一等大路三類一号線と二等大路三類八号線の予定 線を幹線道路として、東西線5 本、南北線8 線が計画された（Fig. 3）。また向島内堀を埋設して市街地とし、漁師町水門付近に漁船 
30-40隻収容する船溜所を1力所と、京橋川と大橋川をつなぐ運河 (幅員6-7間) を設けることも計画された。その後、区画整理の計画 が決定するまでは、市街地建築物法施行細則第十一条第三号にそく して罹災地一帯において本建築の建設は認めない方針であり、あわ せて建築線の指定も行われた（昭和6年5月26日県告示）注32）。

以上の基本方針にもとづき、松東土地区画整理組合（組合長 : 石 倉俊寛松江市長）では「設計書」注33）を作成し、昭和6年7月12日に 各種の認可申請を行っている。「設計書」の整理施行の目的には 「本地区将来永遠ノ重要施設ニ対シ根本的計画 $ᄏ$ 樹立シ復興事業) 完成 通、保安、衛生、経済上等ノ欠陥 $习$ 補七専ラ宅地トシテ利用 $习$ 増進 セントス」と記されており、火災復興に向けて、交通や衛生施設の 不備を補いつつ、宅地整備に重点を置いた事業方針だったことが窅 える。Fig.5の区画整理前後の比較でも、田畑と水面の面積が大幅に 減少する一方、宅地と道路の面積が増加していることから、農地の 宅地転用と京橋川の埋立によって、一定幅員の道路用地を確保する とともに宅地整備が行われたことがわかる。

ところで、松東の土地区画整理については、Fig3に示すように単 純な矩形の街区割になっていた。換地計画についても「設計書」か ら「換地、新設街路二接シ建築二便スルタメ可成直角二区分シ面積 八従前ノ土地台帳地籍二比例セシムモノトス」とあるように、建物 を建てやすくするためにできるだけ矩形の街路に直交するように区 画し、面積も従前の土地面積に比例させるという方針になってお り、それにもとづいて短冊型の敷地に町家形式の店舗兼併用住宅が 建ち並ぶ一般的な市街地が再建された（Fig.4）。このようにわざわ ざ都市計画技術官僚を招聘したにもかかわらず、単純明快な街区・ 画地の計画が策定された背景には、早急な復興の必要性に迫られて いたことが挙げられよう。

罹災地復興を目的としていた松東の土地区画整理は、組合施行で はあったものの、石倉市長が組合長を務めているように、実質的に は公共的な事業であった。こうした事業手法が取られた理由には、 昭和9年12月の都市計画法改正までは、同法第十三条において土地区 画整理は認可後 1 年以内に施行に着手するものがいない場合に限って 公共団体施行が認められることになっていたことが挙げられる。い うまでもなく火災復興は早急に行わなければならないが、罹災した 地権者による組合の結成は難しいため、松江市が工事費を負担し、 組合は事務費4,800円のみを負担することで速やかな事業化に漕ぎ着 けており、昭和8年6月の時点で9割が完了していたという注34)。ただ し一部の換地には時間を要し、最終的には昭和16年1月に完了した。

\section{6. 戦時疎開の後処理：生産再建整備都市計画街路事業}

松江市では、昭和 20 年度に入って「建物強制踈開跡地道路広場計 画」注35）を作成し、7月中に内務省の決定を受けて確定する見込みだ ったが、市街地建築物法、建築調査令、臨時建築制限令によって面 積、構造、場所等の建築規制を行うために、参考までに 21 力所の疎 開跡地の道路広場を公表している。

終戦後、戦災の被害を受けなかった松江でも、強制疎開の跡地処 理のために生産再建整備都市計画事業が実施されることになった。 同事業の決定理由書（昭和21年11月9日内 務省告示第168号）には つぎのように記されている。

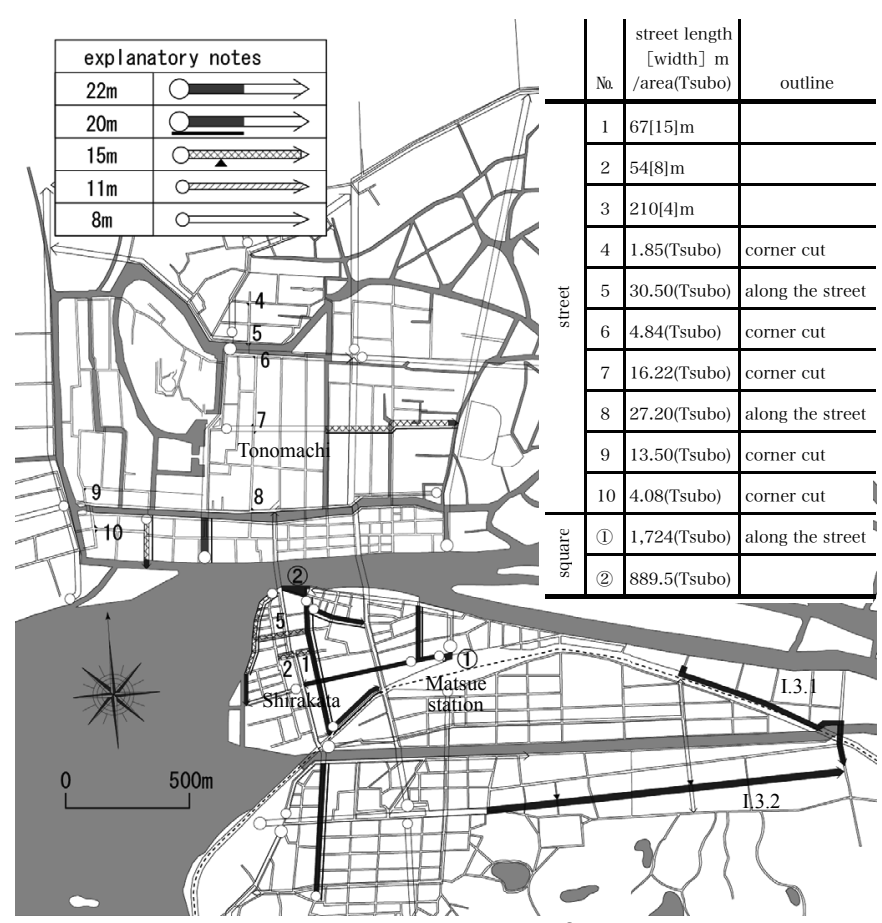

Fig.5 Production city reconstruction project after W.W.II in the possession of Shimane prefectural official archive center.

「松江生産再建整備都市計画街路及び同事業並びにその執行年度割決定」

理由書 建物疎開跡地の内、都市計画上必要なるものを採り上げてこれを広 場又は街路広場とし、同時に生産再建整備事業として決定経済復興乃至生産の 充実に資せしめようとするものである

この史料から建物疎開跡地の後処理として広場ないし街路広場の 設置が計画されたことがわかる（Fig.5）。旧城下町以来、商業地と して賑わい、密集市街地だった駅前から白潟本町周辺と（Fig.5-1 • $2 \cdot 5 \cdot$ (1)・(2)）そこから橋北の殿町に抜ける道路沿いの交差点で隅 切りが計画されていたことがわかる（Fig.5-4〜8）。また松江城の南 側でも一部事業が行われている（Fig.5-9・10）。一方で、経済復興 に向けた生産再建に関わる広域道路の計画も含まれていた。具体的 には市街東部の二等大路三類一号線・同二号線が該当している。

松江市の生産再建整備都市計画事業は昭和 22 年度から 24 年度にか けて事業化される計画になっており、初年度に用地貸借、最終年度 の築造工事が行われることになっていた。このため、松江生産再建 整備都市計画街路事業及びその執行年度は、昭和23年3月31日付で決 定され、4月27日に告示された（建設院告示第149号）。昭和22年度 には生産再建整備事業の一環として二等大路三類一号線の整備が事 業決定している。その決定理由書にはつぎのように記されている。

さきに松江都市計画として事業決定を見た二等大路二類八号線（停車場大橋 線）と関連して松江港及び同工業地とを結ぶ重要路線であるが街路の破損等甚 しいので生産再建整備事業として決定し松江市長をしてこれを執行せしめ、近 隣戦災都市に対する生産供給源として整備すると共に、松江市健全なる発展に 資せんとするものである。

この記述から松江市を近隣の戦災都市に対する生産供給源として 位置づけ、工業地と松江港を結ぶ重要路線としてこの都市計画街路 が整備されたことがわかる。同街路の整備は昭和26-27年に一部計画 変更・事業変更され、昭和28-30年度にかけて舗装工事が行われた。 


\section{おわりに}

法定都市計画の適用に向けて実施された都市計画準備調査は、人 口増加率等の客観的な数值を示したものであり、都市計画区域の設 定において重要な根拠になった。けれども具体的な都市計画の策定 段階で調査結果が直接反映されることはなかった。ただし湖岸道路 は、基礎調査から延々と継承されたと推察されるが、戦前の時点で は都市計画決定されなかったものの、一部が失業救済事業として事 業化され、戦後に都市計画道路として公園とともに整備され、現 在、観光都市・松江を象徵する都市空間となっている。

一方、都市計画事業による基盤整備は、国庫補助の交付された松 江の南北の主要幹線である一等大路三類一号線が失業救済事業とし て整備されたのにとどまった。けれども都市計画事業以外にも、(1) 斐伊川改修の一環としての埋立事業、(2)国と県による道路改良、(3) 失業救済事業、(4)災害復興土地区画整理、(5)建物強制疎開跡地の処 理という点から一定の成果が上げられたことが明らかとなった。(1) に関しては、水都・松江の特徵だと考えられるが、都市整備にあた ってどうしても水面の埋立が必要であり、内務省の巨大プロジェク トだった斐伊川改修事業の一環として浚渫された土砂を松江駅南側 の耕地整理や湖岸道路の一部、火災復興の京橋川埋立などに利用 し、都市整備を促進した。(2)と(3)に関しては、昭和恐慌後に失業救 済事業とともに、国府県道の道路改良が広域的に推進されたことが すでに指摘されているが注36)、松江でも同様の事業が確認された。 (4)に関しては都市計画手法としては一般的なものであったが、松江 では四ヶ所の火災復興土地区画整理によって中心市街地の更新が行 われた。なかでも大規模火災が発生した松東地区では、当時の都市 計画法では土地区画整理の認可から 1 年は公共団体が事業を施行する ことはできなかったため、市長自ら組合長となり、市が工事費を負 担することで半公共的な事業として緊急的に復興が進められていた のである。昭和 9 年 12 月に都市計画法が改正され、公共団体が災害復 興の土地区画整理事業を施行できるようになるまで、各地で半公共 的な復興が工夫されていたが注37)、松東の事例もその一端として位 置づけられよう。(5建物強制疎開の跡地処理にあたって生産再建整 備都市計画事業が実施されており、戦災復興のように都市構造を改 変するほどの大規模な事業ではなかったが、非戦災都市の整備に寄 与していたことが示唆されるのである。

本稿で取り上げた松江の事例は、法定都市計画事業がほとんど機 能しなかった戦前の地方都市においても、さまざまな調査や議論を 行い、(1)〜(5)でみたような都市整備を積み重ねることによって、地 味ながらも着実に市街地を更新していった典型例として位置づけら れよう。

\section{謝辞}

科研費（基盤B：26289215／18H01603）の成果の一部である。

注

注1）野中勝利「城下町都市の戦前の街路計画と都市的拠点との関連」（『日 本都市計画学会学術研究論文集』28、pp.229-234、1993) ほか一連の 研究や浅野純一郎『戦前期の地方都市における近代都市計画の動向と展 開』（中央公論美術出版社、2008）等、枚挙にいとまがない。

注2）例えば、佐藤滋『城下町の近代都市づくり』（鹿島出版会、1995）P.58 等で指摘されている。
注3）前揭『戦前期の地方都市における近代都市計画の動向と展開』P.210でも 長野市を事例とした検討から、都市計画街路事業よりも失業者救済事業 や国道や県道などの道路建設によって街路整備が進められたことが指摘 されている。地方都市の場合、史料の制約は大きいが、こうした観点か ら事例研究を蓄積し、戦前の地方都市における都市計画を法定都市計画 以外の事業も含めて再評価する必要があると考元られる。

注4）上野富太郎・野津静一郎『松江市誌』（松江市、1941）。

注5）脇田祥尚ほか「城下町を基盤とした近代都市計画の展開〜松江市におけ る都市施設の分布と街路計画に着目して〜」（『日本都市計画学会学術 研究論文集』34、pp.557-582、1999）。

注6）奥村久雄所蔵「松江の進展」（昭和初期）所収。なお適宜、句読点を補 っているほか旧漢字は常用漢字に直している。以下の引用史料も同じ。

注7）いず扎奥村久雄所蔵「松江の進展」（昭和初期）所収。

注8）後藤・安田記念東京都市研究所所蔵「都市計画島根地方委員会議事速記 録」（第一回、昭和三年九月四日、10頁）には「（前略）昨年末焼失シ タル地区ヨ復興スル為入土地区画整理施行スル為メニ八是非松江都市計 画区域内二於テ施行スル)必要ニシテ且至便デアルト謂フ特殊ナ事情ガ アリマス（後略）」とある。

注9）後藤・安田記念東京都市研究所所蔵「都市計画島根地方委員会議事速記 録」（第二回開会、昭和四年十二月二十四日）には「松江市八一面二於 テ遊覧都市ノ設備ヨセネバナリマセン、ソウシテ見マスト此濱佐陀川迄 ノ沿岸八最モ景勝ノ地デアリマス、又現二松江市街ノ距離カラ申シマシ テモ、余リサウ距離モアリマセンシ、抑々遊覽地トシテ施設ヨシマスニ 八此方面八近キ将来二於テ何等力具体化スルモノト思ヒマス、成ルベク ナラバアノ辺迄习編入シタイモノ」と記されている。

注10）後藤・安田記念東京都市研究所所蔵「都市計画島根地方委員会議事速記 録」（第三回開会、昭和七年十一月八日）。

注11）前揭「都市計画島根地方委員会議事速記録」（第三回開会）。

注12）前揭「都市計画島根地方委員会議事速記録」(第三回開会)。

注13）「松江築港の利用方法」（「港湾」9-12、昭和6年12月号）。

注14）島根県公文書セン夕ー所藏「第 $3 \cdot 4 \cdot 6 \cdot 7 \cdot 8 \cdot 9 \cdot 10$ 回 都市計画審 議会関係緅」（島根県道路課、昭和 20 年度）。

注15）『都市公論』（14-11、p.82、1931.11）

注16）例えば、越澤明『復興計画』（中公新書、2005）pp.97-100等

注17）『都市公論』（16-7、p.114、1933.7）。

注18）前掲「第 $3 \cdot 4 \cdot 6 \cdot 7 \cdot 8 \cdot 9 \cdot 10$ 回 都市計画審議会関係経」。

注19）前掲「第 $3 \cdot 4 \cdot 6 \cdot 7 \cdot 8 \cdot 9 \cdot 10$ 回 都市計画審議会関係経」。

注20）前掲「第 $3 \cdot 4 \cdot 6 \cdot 7 \cdot 8 \cdot 9 \cdot 10$ 回 都市計画審議会関係緅」。

注21）国立公文書館所蔵「国土都市計画 島根県・熊本県」（昭和19年）。

注22）国立公文書館所蔵「国土都市計画 島根県・熊本県」（昭和19年）。

注23）国立公文書館所蔵「国土都市計画 島根県・熊本県」（昭和19年）。

注24）石倉俊宽「湖岸道路問題に就て」（「松江市公報」号外（昭和五年二月 十六日）松江市役所発行）

注25）石倉俊寛「湖岸道路問題に就て」（「松江市公報」号外（昭和五年二月 十六日）松江市役所）には「元来計画予定は湖北線から始めるのであり ますが、其の埋立関係工事費十六万八千余円は先つ現在末次埋立を順次 所要に応じて売却し五年度より七年度に亘り施工し、次に湖南線中松江 市内埋立関係工事費十四万二千余円は末次現在埋立地の残地及湖北線埋 立に依り生じたる余剩地を売却し昭和七年度より九年度に亘り施行し （中略）前後十ヶ年度に亘り確実なる埋立地等を売払ひたる収入を以て 工事を第一期第二期第三期第四期に分つて逐次施行する」とある。

注26）「松江市の湖岸道路（島根）」（『都市公論』14-9、p.84、1931.9） に「なおいよいよ工事に着手することになれば失業救済の意味を多分に 含め工事に使用する人夫その他実人員約一万三千人は失業登録名簿を作 成して失業者に優先権を与へ極力救済するはずである」とある。

注27）「都市計画島根地方委員会作成史料」（筆者所藏）

注28）『都市公論』（16-6、pp.291-292、1933.6）。

注29）『都市公論』（16-6、pp.291-292、1933.6）。

注30）「山陰新聞」（昭和6年5月19日）。

注31）「山陰新聞」（昭和6年5月20日）。

注32）「山陰新聞」（昭和6年5月19日）。

注33）島根県公文書センター所蔵「地籍」（島根県土木部、昭和7年）所収 「耕地整理法施行規則第八条ノ規定二依儿設計書」。

注34) 『都市公論』（16-6、pp.291-292、1933.6）。

注35）松江市所蔵「建物疎開跡地に関する件」昭和20年度。

注36）岡田知弘「重化学工業化と都市の膨張」（成田龍一編『都市と民衆』 pp.196-236、吉川弘文館、1992）等。

注37）前揭『復興計画』等。 


\section{IN A LOCAL CITY IN THE PREWAR PERIOD}

- With reference to the case of Matsue city -

\section{Shigeo NAKANO*1}

${ }^{* 1}$ Prof., Graduate School of Human life Science, Osaka City University, Ph.D.

This study aims to clarify the realities of city improvement in the prewar period by studying the history of devising a city plan as well as the implementation of the plan and projects other than city planning in a local city with reference to the case of Matsue City. Matsue City designated areas subject to city planning on the basis of a preparatory city planning survey. Road networks proposed in the city planning preparatory survey were not necessarily translated exactly into streets as envisioned in the city plan; however, the lakeside roads constructed survived down to the postwar period and ended up as park roads, although they were not incorporated into the official city plan. The city-planning project of Matsue City ended up with only one city-planned street being developed as a state-aided unemployment relief project. However, it is clear that the civil development plans achieved a certain degree of success as evidenced by the landfill project implemented as part of the partial rerouting of the Hii River, road improvement by central and prefectural authorities, an unemployment relief project, land readjustment of fire-damaged areas, and the forced relocation of buildings.

The Hii River project facilitated city improvement because soil dredged from the river was used as landfill to improve farmland behind Matsue Station, improve lakeside roads, and to fill in parts of the Kyobashi River. At the same time, roads were improved and the layout of city streets was altered as an unemployment project. The readjustment of reconstituted fire-damaged land in the Shoto area was implemented by a city planning association, but it was a semipublic project because the mayor of Matsue City was made president of the association and because the city bore the construction cost. The project facilitated the improvement of the city center in terms of sidewalks. A reconstruction project implemented as post-treatment of the forced relocation of buildings was the starting point for the postwar city planning of cities that were not damaged by the war, although the project was not as big as the reconstruction plan for war-damaged areas undertaken during the postwar period. 